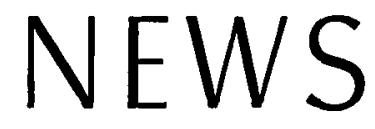

\title{
THE INTERNATIONAL CONGRESS OF HISTORICAL SCIENCES
}

It was generally expected that the 12th International Congress of Historians in Vienna (August 19-September 5) would attract a large number of historians from countries formerly within the confines of the Austro-Hungarian monarchy. True, the inhabitants of the former component areas of the monarchy have for more than forty-five years been living apart in what has sometimes appeared to be "watertight nationalistic compartments" which seemed to serve as effective barriers to the flow of both goods and ideas. Moreover, the broad range of themes on the agenda appeared to exclude the possibility that considerable attention would be paid to the affairs of the old monarchy. Nonetheless, the former areas of the monarchy were well represented at the congress. Among the 2170 active and passive participants, 58 were from Czechoslovakia. The Hungarian delegation consisted of 42 scholars. The Yugoslavs counted for some 50 ; and 35 Rumanians and 25 Poles were in attendance. In addition, there were 115 registered Austrian participants.

Furthermore, there were numerous participants from other countries whose main field of study lies in the Habsburg monarchy. Among the Italians there were Professors Valiani and Valsecchi. Jacques Droz, of France, gave a public lecture on "Socialism and the Nationality Question at the End of the Nineteenth Century;" and his fellow-countryman, V. L. Tapié assessed Vienna's cultural mission in the closing session of the Congress, ${ }^{1}$ together with Professor E. Zöllner, of Vienna. ${ }^{2}$ Among the others there were Hans Mommsen and Peter Burian, of the German Federal Republic; Fritz Klein, of the German Democratic Republic; C. A. Macartney and Hugh Seton-Watson, from Great Britain; Robert A. Kann, Hans

'In a lecture entitled "La place de Vienne dans la culture européenne."

'In a lecture on "Die kulturelle Ausstrahlung Wiens." 
Kohn, Hajo Holborn, Enno Kraehe, R. John Rath, Carl Schorske, John Snell, Stephen Fischer-Galati, and Peter Sugar, from the United States; and, last but not least, the two scholars of Austrian birth who are now professors in German universities, Adam Wandruszka, of Cologne, and Gerald Stourzh, of Berlin.

That the discussion on "The Peasant Movements in Central and Southeastern Europe from the Fifteenth to the Twentieth Century"3 was dominated by scholars from the areas concerned was no surprise; neither was it astounding that the sessions dealing with "The Striving of the Balkan Peoples for Political and Economic Independence from 1875 to 1914" and "The Genesis of Peoples and States in Medieval Central Europe"5 became "rallying grounds" for "native" historians. The printed reports, which served as bases for discussion, had been submitted almost exclusively by scholars from these areas.

Quite naturally, the Habsburg monarchy was also referred to in other sessions of the Congress, such as those on "The Ruling Classes from Antiquity to Modern Times;"B "Religious Tolerance and Heresy in Modern Times;"7 "The Economic and Social Bases of Absolutism;"8 "The World in 1815 ;" "The Political Problems of World War I;"10 "Eco-

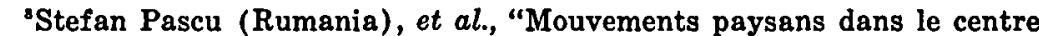
et le sud-est de l'Europe du XVe au XXe siècle," Rapports du XII Congrès International des Sciences Historiques 1965 (Vienna: Berger Horn, 1965), Vol. I, pp. 211-237.

'Dimitrije Djordjević (Yugoslavia), "Les mouvements pour l'indépendance nationale et économique des Balkans au $\mathrm{XIX}^{\circ}$ et $\mathrm{XX}^{\mathrm{e}}$ siècle (jusqu'à 1914), ibid., pp. 237-255.

'František Graus (Prague), C. Daicoviciu (Bucharest), E. Petrovici (Cluj), et al., "Les débuts des états du Moyen Âge en Europe centrale," ibid., Vol. IV, pp. 103-111.

"Branislav Djurdjev, "Stände, Klassen und die Revolution in der Geschichte," ibid., Vol. I, pp. 375-389.

"Erika Weinzierl-Fischer, "Der Toleranzbegriff in der österreichischen Kirchenpolitik," ibid., pp. 135-151.

"Erik Molnar, "Les fondements économiques et sociaux de l'absolutisme," ibid., Vol. IV, pp. 155-171; Hanns Leo Mikoletzky, "Die Anfänge der Industrie und der Staatsfinanzen in Osterreich im 18. Jahrhundert," ibid., pp. 191-201; and Hans Sturmberger, "Das Problem der Vorbildhaftigkeit des türkischen Staatswesens im 16. und 17. Jahrhundert und sein Einfluss auf den europäischen Absolutismus," $i$ bid., pp. 201-211.

"Le Bilan du Monde en 1815" was a program arranged by French historians, and the Habsburg monarchy received very little attention in it.

${ }^{10}$ Friedrich Engel-Janosi (Vienna), "Die Friedensbemühungen Kaiser Karls mit besonderer Berücksichtigung der Besprechungen des Grafen 
nomic and Social Problems of World War I,"11 "Federalism and Federal State in History ;"12 and "Nationalism and Internationalism in the Nineteenth and Twentieth Centuries."13 Thus, of the 33 thematic sections of the program, three dealt directly with Central and Southeastern European history-the geographical location and sphere of influence of the Habsburg monarchy. In eight sections particular aspects of the monarchy's variegated life were discussed within the wider horizon of a large theme.

After reading the program Barraclough wrote that the Congress was a Europe-centered affair which lacked a truly universal tone in so far as the participants and the make-up of the program were concerned. ${ }^{14} \mathrm{~A}$ person might well come to another conclusion after looking at the impressive stack of volumes and other honorary gifts which were presented to President Engel-Janosi at the inaugural session, although with a few exceptions, most of these books were published in Europe-a number of them in that part of Europe which was once within the orbit of the monarchy.

As had been the case at the former congresses at Rome (1955) and Stockholm (1960), the National Committees of Hungary, Czechoslovakia, Rumania, Bulgaria, and Yugoslavia had prepared voluminous collections of articles and bibliographical lists pertaining to the history of their countries for presentation at the International Congress. Furthermore, the Arbeitsgemeinschaft für die Geschichte Osterreichs and a committee of the Deutsche Historiker-Gesellschaft (Democratic Republic), in cooperation with their Hungarian colleagues, recently published the contributions which were made at a conference on Austria-Hungary in World Politics, 19001918, which took place at Budapest in May, $1964 .{ }^{15}$ These pub-

Revertera mit Comte Armand," Rapports du XIIe Congrès des Sciences Historiques, Vol. IV, pp. 279-296.

${ }^{11} \mathrm{~A}$ report with the identical title in Russian was prepared by a Russian team. See ibid., Vol. I, pp. 255-270.

${ }^{12}$ By Robert A. Kann. See ibid., Vol. IV, pp. 33-48.

${ }^{13}$ By Hans Kohn. See ibid., Vol. I, pp. 191-240. See also Leo Valiani (Italy), "Le correnti politiche italiane e la dissoluzione dell'AustriaUngheria (1914-1918)," ibid., pp. 251-256; and Victor Cherestesiu (Rumania), "Die internationale Bedeutung der Revolution des Jahres 1848," ibid., pp. 257-270.

${ }^{14}$ Die Presse (Wochenendbeilage), August 28-29, 1965.

${ }^{16}$ Osterreich-Ungarn in der Weltpolitik 1900-1918, edited by Fritz Klein (Berlin: Akademie Verlag, 1965). See also Charles Jelavich, 
lications are highly welcome, not only because they are written in Western European languages (with occasional Russian texts), but also because they either illustrate "l'évolution la plus recente des sciences historiques"18 or else, as the Yugoslavs have stated, they are "un manuel commode."17 The following statement in the introduction to the Bulgarian volume indicates the general tenor of all these publications when dealing with modern history: "On y étudiera tout particulièrement le développement économique et culturel des peuples des Balkans au cours de ces derniers siècles, ainsi que la politique des grands pays d'Europe dans cet espace, l'engagement des pays balkaniques dans le système des contradictions impérialistes, l'apparition et le développement du mouvement ouvrier et du mouvement socialiste."18 Not only the index of the Hungarian volumes, but also the enlarged edition of the oral reports further illustrates the main trends of East European historical writing. ${ }^{19}$ Conspicuous in these publications ${ }^{20}$ is the virtual absence of Geistesgeschichte and of historiographical reflections, as well as the preponderance of purely national, if not to say local, affairs in the oral discussions.

In contrast to what the historians of the Succession States have published, the Austrians brought out nothing similar. Might it have been possible to avoid the overstressing of the German war guilt question at the Congress and to place more emphasis on Austria's role in the sessions on World War I

"Habsburg Conference in Budapest," Austrian History Yearbook, Vol. I, pp. 291-293.

${ }^{10}$ Nouvelles études historiques, publiées a l'occasion du XII' Congrès International des Sciences Historiques par la Commission Nationale des Historiens Hongrois (2 vols., Budapest: Akadémiai Kiadó, 1965), p. 9. ${ }^{17}$ Historiographie Yougoslave 1955-1965, edited by Jorjo Tadić (Belgrade, 1965).

${ }^{29}$ Etudes Balkaniques, edited by N. Todorov, et al. (Sofia, 1964), Vol. I, p. 8.

${ }^{10}$ See especially E. Máluysz, "Les débuts du vote de la taxe par les Ordres dans la Hongrie féodale," Nouvelles études historiques, Vol. I, pp. 55-82; Gy. Ember, "Zur Klassenpolitik des Habsburgerabsolutismus in Ungarn in den Sechziger Jahren des 18. Jahrhunderts," ibid., pp. 389-414; and E. S. Vincze, "Kampf um die Schaffung einer sozialistischen Massenpartei in Ungarn (1848-1900)," ibid., Vol. II, pp. 95-120.

${ }^{20}$ Nouvelles études d'histoire, publiées à l'occasion du XIIe Congrès des Sciences Historiques (Bucharest, 1965) ; Historica, edited by Josef Macek (Prague: Ceskoslovenské Akademie Věd, 1965); Studia Historica Slovaca, edited by Lodovit Holotík, et al. (Bratislava: Vydavatel'stvo Slovenskej Akadémie Vied, 1965), Vol. III; Etudes historiques à l'occasion du XII Congrès International des Sciences Historiques, edited by Dimitar Kosev, et al. (Sofia, 1965), Vol. II. 
if the Austrian historians had previously published a relevant volume, like, for instance, a book devoted to the contributions which scholars from both camps made to the events centered around June 28, 1914, at the Belvedere symposium?21 As it turned out, the discussions on World War I at the International Congress were mainly concerned with the German question, and as such amounted to a continuation, though a less passionate one, of the Berlin meeting of German historians in 1964, at which the ideas in Fischer's Griff nach der Weltmacht and the underlying theses of this concept were so passionately debated. Despite Engel-Janosi's masterly discussion of the Austrian peace efforts of 1917-18, and despite Hantsch's comprehensive biography of one of the important Austrian political figures involved in the events of $1914,{ }^{22}$ it was Bethmann-Hollweg's, and not Berchtold's, personality and concepts which dominated the session. As for the discussions about Austria during the course of the war, the leitmotiv was that of dissolution and disruption, of "mass rebellion," and of "popular resistence," 23 even though the Austrian historians Engel-Janosi and Plaschka (with factual knowledge derived from Cattaro and Prague) ${ }^{24}$ strongly contested this point of view.

Those attending the meeting of the Habsburg Commission, which was presided over by Professor Hantsch, were well aware of the fact that a comprehensive study needs to be made of many basic problems of the Habsburg monarchy. Professor Hantsch told the group that the long-standing plans for a comprehensive study on the monarchy were to be executed by the concerted action of scholars from both the East and the West. Plans for bibliographical cooperation like those which Prof. Chereștesiu reported were already in operation between Yugoslavia and Rumania, as well as agreements about the mutual use of archives and libraries, would be of great value to the whole project.

\footnotetext{
"See Helmut Rumpler, "Austria-Hungary and the Outbreak of World War I," Austrian History Yearbook, Vol. I, pp. 286-289.

"Leopold Graf Berchtold, Grandseigneur und Staatsmann (2 vols., Graz: Styria, 1963). See the review of this volume in the Austrian History Yearbook, Vol. I, pp. 273-278.

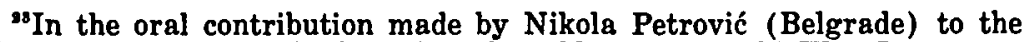
discussion dealing with the political problems of World War I.

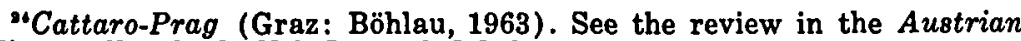
History Yearbook, Vol. I, pp. 278-279.
} 
In way of conclusion, this writer wishes to raise the question of whether the study of reciprocal cultural influences might possibly result in the development of a new approach to the study of the causes for the monarchy's rise and decline to replace the overemphasis on nationalistic factors during recent decades? Could "acculturational research" offer a new answer to the question of why no feeling of "Gesamtstaatsbewusstsein" developed in the old monarchy.

University of Vienna

Grete KLINGENSTEIN

\section{NEWS FROM AUSTRIA ${ }^{1}$}

\section{PERSONAL}

Hugo Hantsch, professor of modern history and director of the Historical Institute of the University of Vienna since 1946, celebrated his seventieth birthday on January 15, 1965. The name of this distinguished scholar, who is well known for his studies on Austrian history from the baroque era to the present, is especially connected with the rebuilding of the study and research programs of the Historical Institute after 1945. At a special ceremony at the Historical Institute Professor Hantsch was presented with a Festschrift entitled österreich und Europa. This volume was edited by Heinrich Fichtenau and published jointly by the Institut für Osterreichische Geschichtsforschung and the Wiener Katholische Akademie. In his capacity as founder and director of the Commission of the Austrian Academy of Arts and Sciences for the Study of the History of the Austro-Hungarian Monarchy, 1848-1918, Professor Hantsch has particularly made a laudable contribution to the development of close co-operation between American and Austrian historians in the field of Austrian studies. The editor of the Austrian History Yearbook is especially happy to express his appreciation to Professor Hantsch for his sympathetic assistance and co-operation.

In May, 1965, Richard Plaschka, secretary of the Osterreichische Ost- und Südosteuropainstitut (formerly Arbeitsgemeinschaft Ost) was appointed ausserordentlicher Professor

\footnotetext{
"The large majority of items in the "News from Austria" section were supplied by Helmut Rumpler, of the University of Vienna.
} 